\title{
SOME NOTES ON THE IDEA OF LIVING HUMAN DOCUMENT AND ITS IMPLICATIONS FOR PASTORAL PRAXIS
}

\begin{tabular}{|c|c|}
\hline \multicolumn{2}{|c|}{$\begin{array}{l}\text { Alokasih Gulo } \\
\text { Sekolah Tinggi Teologi Banua Niha Keriso Protestan Sundermann, } \\
\text { Indonesia } \\
\text { Email: okagulo@gmail.com }\end{array}$} \\
\hline ARTICLE INFO & ABSTRACT \\
\hline $\begin{array}{l}\text { Received: } \\
\text { December, 26th } \\
2021 \\
\text { Revised: } \\
\text { January, 17th } \\
2022 \\
\text { Approved: } \\
\text { January, 18th } \\
2022\end{array}$ & $\begin{array}{l}\text { This article provides a review of the literature on the } \\
\text { concept of a living human document, which was first } \\
\text { proposed by Anton T. Boisen and then advanced by Charles } \\
V \text {. Gerkin. I will apply a holistic approach to understanding } \\
\text { the idea of a living human document in light of the } \\
\text { increasingly complicated difficulties humans face in our } \\
\text { modern day. In this article, I argue that taking a holistic } \\
\text { perspective will help us better comprehend persons in their } \\
\text { environments (internal and external contexts). This, as I call } \\
\text { it, is an attempt at holistic pastoral theology based on living } \\
\text { human document. }\end{array}$ \\
\hline KEYWORDS & $\begin{array}{l}\text { Living Human Document, Clinical Pastoral Education, Holistic } \\
\text { Pastoral Praxis }\end{array}$ \\
\hline (c) (i) (2) & $\begin{array}{l}\text { This work is licensed under a Creative Commons } \\
\text { Attribution-ShareAlike } 4.0 \text { International }\end{array}$ \\
\hline
\end{tabular}

\section{INTRODUCTION}

Pastoral theology - as well as other theories in theology - is a reflection of practical experience and human struggles which is then compiled and developed in a systematic and theoretical manner. Pastoral theology was born and developed from actual human experience with all the complexities of life. Pastoral theology like this implies a close relationship between pastoral theology itself and the reality of human life. As a result, the pastoral ministry that is carried out will touch the concrete struggles of people who are in crisis.

\begin{tabular}{cl}
\hline & Alokasih Gulo.(2022). Some Notes on the Idea of Living Human \\
& Document and Its Implications for Pastoral Praxis. Journal Eduvest. \\
How to cite: & Vol 2(1): 140-149 \\
E-ISSN: & 2775-3727 \\
Published by: & https://greenpublisher.id/
\end{tabular}




\section{Alokasih Gulo}

Anton T. Boisen, in (Kemp, 2004) in his work "The exploration of the inner world" and "Out of depths: An autobiographical study of mental disorder and religious experience",(Boisen, 1960) understands the concrete experiences of humans who are in the crisis as the living human document. According to him, theology and pastoral ministry must be built and developed based on the living human document. Charles V. Gerkin also emphasizes this in his work "The Living Human Document: Revisioning Pastoral Counseling in a Hermeneutical Mode," namely that human stories (experiences) should be the primary basis in building pastoral theory or theology.Charles V. Gerkin, Konseling Pastoral dalam Transisi (Jakarta \& Yogyakarta: BPK Gunung Mulia \& Kanisius, 1992).

This article is a study of the idea of a living human document originally initiated by Boisen and later forwarded by Gerkin. In connection with the increasingly complex problems humans face in this contemporary era, I will use a holistic approach to understanding living human documents. This approach will significantly help us understand humans comprehensively in their contexts (internal and external contexts). I call this approach an attempt at holistic pastoral theology based on living human documents.

This article begins with a brief description of the early history of the emergence of the concept of a living human document, describing the initial struggles of Boisen and other patients in mental hospitals as the starting point for the theology and pastoral ministry that he initiated. What follows is the basic concept of living human documents by Boisen and Gerkin, followed later by my operational definition of living human documents. The following section is the essence of this article, which is about a new alternative in understanding humans: a holistic pastoral approach based on living human documents.

\section{RESEARCH METHOD}

This study uses library research methods that refer to sources available both online and offline such as: scientific journals, books and news sourced from trusted sources. These sources are collected based on the discussion and are linked from one information to another. All activities in the context of data collection and analysis are carried out online considering the limitations of open movement in public spaces. This data is obtained through triangulation techniques, the data is analyzed and then conclusions are drawn.

\section{RESULT AND DISCUSSION}

\section{The Early History Of The Emergence Of The Concept Of Living Human Documents}

The living human document is a concept that was introduced by Anton T. Boisen, a pioneer of Clinical Pastoral Education (CPE) in America in 1925. This term has become a key concept in clinical pastoral education until today. According to Boisen, these living human documents are documents that can be read and understood, just as when we read and understand books or written documents, such as biblical texts.Boisen, The Exploration of the Inner World, 10, 185.

This concept was motivated initially by Boisen's own experience. First, in 1920, Boisen experienced a mental illness - a catatonic type of schizophrenia - for which he had to be admitted to a mental hospital.Mesach Krisetya, 1990. Based on this 
experience, Boisen emphasized that the main problem is not a medical problem but a religious one. This problem should be the main focus of the companions, in this case, the pastors.Anton T. Boisen, 2005. He also saw that this struggle was experienced by the patients who were with him at the hospital. Unfortunately, no one paid any attention to him while he was in the hospital. No pastors visit and listen to their stories. As a result, Boisen and other patients continued to search for the meaning of their religious experiences without the guidance or assistance of pastors who had studied theology.

Second, Boisen and the other patients were allowed to attend Sunday afternoon services at the hospital. At first, he was happy with the service, but then he was disappointed because the ministry of the servants did not touch the problems they were facing. Boisen expressed his disappointment and concern by sharing his experience:

I was very happy to find that there were religious services on Sunday afternoons. But I soon discovered that the ministers from neighboring village who counducted those services might know something about religion, but they certainly knew nothing about our problems. All they did was to conduct a formal service on Sunday afternoons, and for lack of anything better they usually gave us the same sermons they had given their own congregations in the morning. There was one kindly old minister who gave us a series of sermons on missions missions in China, missions in Africa, missions in Japan. Another preached on the text, "If thine eye offend thee, pluck it out." I was afraid that one or two of my fellow patients might be inclined to take that injunction literally.Boisen, The Exploration of the Inner World, 5-6.

The question is why did the preachers' sermons not touch the realities of the lives of Boisen and his fellow patients? According to Boisen, this is because pastors have never met people in life crises, never been to patient rooms, spaces where real struggles exist. Boisen saw that the clergy did not have a strong urge or enthusiasm to visit and meet patients in hospitals.Boisen, The Exploration of the Inner World, 10. While attending theological education, including pastoral theology, these pastors are only provided with theoretical education and have almost nothing to do with factual data on the human experience. The ministers were never well prepared to meet and read human documents living in all the complexities of their problems. As a result, the theologies produced are highly abstract religious theories and teachings based on written documents such as the Bible, ecclesiastical traditions, and other writings. On a practical level, such theology does not produce pastoral care that touches the realities of life for people in various crises. Consequently, pastoral ministry is nothing more than preaching, teaching, judging, reading Bible texts, and praying. That is why, according to Niklas, such pastoral care becomes monotonous, cold, rigid, and dull.Gerald R. Niklas, 2001.

Departing from the issue of theology, Boisen criticized the theological education system which is more based on written sources. According to him, theology must start from the concrete problems of people who are having problems, namely people who at that time are undergoing treatment in mental hospitals. In this case, Boisen wants to develop an empirical pastoral theology with a case study approach. This is reinforced by Gerkin, namely that fundamentally human experience occurs first, while reflection and the theorizing process come after.Gerkin, Konseling Pastoral dalam Transisi, 30. For Boisen himself, there is no better laboratory than a mental hospital and no library better than living human documents. This process was later referred to by Nouwen as an attempt to theology through living human documents (Nouwen, 1968) 


\section{Alokasih Gulo}

\section{Basic Concepts Of Living Human Documents}

According to Robert C. Dykstra, professor of pastoral theology at Princeton Theological Seminary, the concept of a "living human document," which is now a key concept in CPE, is considered a breakthrough in pastoral theology. That's why Boisen is recognized as one of the pioneers of contemporary Protestant pastoral theology. Robert C. Dykstra, 2005. The breakthrough can be seen in at least 3 (three) things:

First, to develop pastoral theology as empirical theology, namely theology that starts from the practical experience of people with problems. According to Krisetya, initially, Boisen used empirical methods in conducting his research because he aspired to produce empirical pastoral theology.

Second, bringing pastoral theology to its original spirit, namely from theory to practice. It is also a sharp critique of overly theoretical theological education. According to Gerkin, an idea does not exist beforehand and can be applied to practice.Gerkin, Konseling Pastoral dalam Transisi, 30. Pastoral theology departs from practical experience, while the theory emerges later based on that experience. Thus, the encounter with living human documents through field practice becomes the primary tool in pastoral theology.

Third, bringing pastoral theology back to focus on its main field, namely religious life. This effort is essential because the influence of psychology in pastoral theology is too strong. William W. Hulme noted one of the criticisms of the church in terms of pastoral care, namely that the pastoral ministry carried out today had experienced a shift in spirit/soul/value from pastoral to psychology or psychotherapy. William E. Hulme, 1981. The pastoral ministry carried out by churches today tends to lose its uniqueness as a ministry based on "religious traditions." This tendency is not only because of the combination of theology with psychology/psychotherapy, which is the advantage of pastoral care, but also because of the movement of the church (church counselors) to place more importance on deepening psychology or psychotherapy instead of deepening theological concern.

The primary purpose of all these breakthroughs is to help people in various life crises and help pastors themselves grow and develop a theory of pastoral ministry based on the concrete human experience. According to Niklas, pastoral ideas and techniques obtained through classroom learning, reading books, and other written references will only be helpful if the learning can be integrated into actual ministry.Niklas, The Making of a Pastoral Person.

To achieve the above purpose, meeting with people in crisis is significant so that pastors get to know and understand the situation and struggles of people in trouble. Boisen calls an encounter with living human documents, namely encounters with people who are in various life crises, people with all the complexities of their actual social conditions.Boisen, The Exploration of the Inner World, 185. Furthermore, Charles V. Gerkin sees that the encounter with the living human document requires a dialogical interpretation so that it can produce a new hope for those who are in crisis.Gerkin, Konseling Pastoral dalam Transisi.

However, the main limitation of Boisen regarding this concept is that he only starts from his case, although he later includes cases of fellow patients. As a result, the focus of his studies was solely on the interrelationships between patients' religious experiences - which were ignored by psychologists, sociologists, and psychiatrists - and crises related to mental health - which at that time were ignored by the church. In his book "The Exploration of the Inner World," Boisen asserts his central thesis:

As I look around me here and then try to analyze my own case, I see two main classes of insanity. In the one case there is some organic trouble, a defect in the 
brain tissue, some disorder in the nervous system, some disease of the blood. In the other there is no organic difficulty. The body is strong and the brain in good working order. The difficulty is rather in the disorganization of the patient's world. Something has happened which has upset the foundations upon which his ordinary reasoning is based. Death or disappointment or sense of failure may have compelled a reconstruction of the patient's world view from the bottom up, and the mind becomes dominated by the one idea which he has been trying to put in its proper place. That, I think, has been my trouble and I think it is the trouble with many others also.Boisen, The Exploration of the Inner World, 10-11.

Boisen's idea above arises because the study setting is indeed a mental hospital. Still, it seems to reduce the essence of the living human document itself. The problem is that the person in crisis is only in the hospital, while we can find those people everywhere. Another problem is that at the end of his thesis, Boisen generalizes the problem for others. This approach seems complicated for pastors who do not have experience serving in hospitals, especially pastors whose primary ministry is not in hospitals but congregations and communities.

Meanwhile, Gerkin, although generally in line with Boisen to develop pastoral theology based on real human experience and restore the "spirit" of pure theology into theology and pastoral ministry, but his study of living human documents is still too philosophical, as well as the influence of psychology, especially psychoanalysis and other personality theories, are still very strong. This idea certainly makes it difficult for theology students and pastors in the Indonesian context because they do not have adequate knowledge of philosophy and human psychology. Just like his predecessor, Boisen, the approach used by Gerkin is still individualistic.

Therefore, I see that it is necessary to reinterpret the concept of a living human document. In my opinion, living human documents are people - both as individuals and as (social) groups - who, due to one or more internal and external factors, experience a crisis that prevents them from enjoying life as a whole human being. However, in contrast to Boisen's (and Gerkin's) initial concept, which only focused on hospitals (hospitalbased), the documents of people who live here are inside the church; some are outside the church. This idea is based on the fact that in the context of church ministry, people in trouble, who are in various life crises, and people suffering, are everywhere, related directly or indirectly to the situation or inner life of the church.

\section{Towards A Holistic Pastoral Theology Based On Living Human Documents \\ a. A New Approach To Living Human Documents}

In principle, the concept of "living human document" is fundamental in theology and pastoral ministry. Although it originally appeared at the end of the 20th century, I agree with Dykstra, who considers it a breakthrough in contemporary pastoral theology. Of course, some things must be criticized from these previous concepts considering that we are in an era that is already very complex.

With his concept of living human documents, Boisen recommends that the interactions of prospective pastors (theology students) and even pastors with people (individuals) be recorded in the form of cases. The setting of theological development and pastoral care is a mental hospital, where patients become "documents" according to which their inner-world is problematic, and it's all related to issues of religious experience. That is why Boisen places great emphasis on the need to encounter living human documents and read them as much as when reading written texts. However, Boisen - along with the theology students he trains - meets with patients only to find out information about their primary struggles. From this information, a form of pastoral care is designed to touch the 


\section{Alokasih Gulo}

reality of their lives. The problem is that the encounter with the patient does not provide space for dialogue on this living human document so that the resulting pastoral assessment tends to be subjective.

Gerkin later tackled with his theory of "pastoral counseling hermeneutics." He emphasizes the importance of dialogical hermeneutics in the counselor's encounter with his client. According to Gerkin, the counselor, in interpreting the client's story (which is the result of the client's interpretation of his story), his interpretation by utilizing life experiences and previously learned knowledge.Gerkin, Konseling Pastoral dalam Transisi, 30-33. It means the counselor's encounter with the client is a process of listening and interpretation that involves both parties, namely the client and the counselor. This process is referred to as a "dialogical-hermeneutical" process which ultimately results in a new "interpretive story" of the client's experience, a more hopeful story. Gerkin then concluded that pastoral counseling is no longer just the art of listening but is a science and art of interpretation.

However, neither Boisen nor Gerkin elaborated the methods and steps to read and interpret this living human document in more detail. Both ideas are still abstract; moreover, Gerkin's hermeneutical philosophical approach adds to the complexity of interpreting living human documents. Both are also still very dependent (only) on psychology, especially psychoanalysis and other personality theories, in understanding living human documents. The theology and pastoral care they develop are very individualistic and only pay attention to the patient's inner world.

Haarsma disagrees with this highly individualistic theology and pastoral ministry; according to him, self-limitation on maintaining the soul of individuals or small groups is unjustified.F. Haarsma, Pastoral dalam Dunia (Yogyakarta: Pusat Pastoral Yogyakarta, 1991), 24. Pastoral care is not merely directed at liberation from sin, guilt, fear, doubt, despair, and hatred, but also a freedom from the economic, societal, cultural, and political powers preventing humans from becoming human. Pastoral care is focused on the human city and on the people within that city.

The same thing was conveyed by Stephen Pattison, namely that pastoral care directed at individuals does not value togetherness and the existing social aspects.Stephen Pattison, 1988. Therefore, pastoral care cannot be limited only to individuals because many sins, sufferings, crises, and the capacity to grow have their roots outside of human beings. These ideas show that the problems faced by humans as individuals cannot be separated from contexts outside themselves, and this is what must be considered in pastoral care.

Sharp criticism of Boisen's (and Gerkin's) concept also came from Bonnie J. Miller-McLemore, professor of theology and pastoral counseling at Vanderbilt University Divinity School, with his idea of "The Living Human Web".(Miller-McLemore, 2005) Miller-McLemore specifically criticizes Boisen's approach, which is only concerned with the context or the patient's inner world in his concepts and studies. According to him, Boisen's approach to understanding living human documents relies heavily on psychological support and is highly individualistic. This approach is no longer appropriate in an increasingly complex world, where the problems faced by humans are not singular but are shaped and influenced by various interrelated aspects. MillerMcLemore calls her terms "the living human web".

In her studies, Miller-McLemore uses Catherine Keller's feminist approach, "From a Broken Web: Separatism, Sexism, and the Self," and other liberation theology. This approach is meant to show that pastoral theology - in an increasingly complex world- "must hear the voices" of the marginalized from within their contexts". 
In her research, Miller-McLemore found that many marginalized people cannot be served well by using Boisen's living human document approach, especially marginalized women and black people. Boisen's concept of living human documents has yet to answer questions like this, especially since the locus is only in mental hospitals. According to her, pastoral theology's trademark of empathy for the living human document is confounded by the limitations of empathy in the midst of the living human web. Sometimes a person must admit an inability to understand fully the lived reality of the oppressions suffered by another (Miller-McLemore, 2005)

Therefore, Miller-McLemore emphasizes the interconnectedness of theology and pastoral ministry, no longer relying solely on psychological support but social, political, and other aspects. Unlike the concept of a living human document, the living human web cannot simply be "read" (Boisen) and interpreted (Gerkin) like a "document".(MillerMcLemore, 2005) Marginalized people, including women and blacks, still cannot or can't even speak, so how can they be "read" and interpreted? That's why, according to MillerMcLemore, theology and pastoral ministry must be able to encourage the marginalized to speak for themselves.(Miller-McLemore, 2005)

This Miller-McLemore critique is noteworthy. We live in a complex contemporary era, and reliance on psychology alone will not help much theology and pastoral care. The choice of a mental hospital as a "laboratory" to read and interpret living human documents limits the "space" and "reach" of theology and the pastoral ministry itself. Likewise, the approach is very individualistic, not paying attention to the external context that also influences the inner world of the people with problems. However, the concept of "the living human web" from Miller-McLemore also tends to ignore individual aspects of a person because of giving too wide space to the socio-political context. Therefore, in my opinion, a holistic pastoral approach is an excellent alternative in reading and interpreting human documents living in an increasingly complex world.

\section{B. Holistic Pastoral Approach on The Idea Of Living Human Documents}

The term "holistic" comes from the word "holism." This word means the activity of the parts of a whole concerning the function of the whole.Lorens Bagus, Kamus Filsafat (Jakarta: Gramedia Pustaka Utama, 2000), 293. The paradigm of this approach is that the whole is considered a whole, which consists of many different but interconnected parts that influence and form a living organism. To develop holistic theology and pastoral care based on living human documents, we will look at and analyze humans and the problems they face from the physical aspect, psychological/mental aspect, social aspect, and spiritual aspect.Daniel Susanto, Clinical Pastoral Education and Its Significance for Indonesia: A Study of Transfer of CPE from the USA to Indonesia, Illustrated by the CPE Transfer to the Netherlands (Kampen: Drukkerij van den Berg, 1999).

The birth and development of this holistic pastoral approach cannot be separated from the theological reflection of the church or a particular person on the various contexts faced by humans from time to time, and is an attempt to translate the pastoral function into its context. It is realized that the traditional approach in developing theology and pastoral care is no longer effective and efficient in responding to various issues that occur in human life, both individually and in community life, including in various contemporary issues that develop in society. Aart van Beek, a pastoral theologian who has lived and taught in Indonesia for a long time, said that a holistic pastoral approach is the most relevant approach to be applied in Indonesia because congregations and communities still struggle a lot around issues of poverty, social injustice, pluralism, environmental issues. life, and various other socio-economic pathologies.(van Beek, 2002) Then, what kind of holistic pastoral approach is meant? 


\section{Alokasih Gulo}

First, holistic theology and pastoral care are placed within the framework of understanding the wholeness of aspects of human life, namely physical, mental, social, and spiritual aspect. These various aspects of human life are not to be separated or contradicted each other (dichotomies) and are not hierarchical (some aspects are more important than others). Instead, these aspects are interrelated, complementary, and influencing. This approach at the same time fills the gap in pastoral theology, which only looks at human problems from the inner-world side (Boisen and Gerkin) or vice versa from the external human context (Miller-McLemore).

Second, Susanto emphasizes that a holistic pastoral approach must also be understood in the broader dimension or scope, namely every dimension to which God expresses concern or care, Daniel Susanto, 2010. or in Lartey's language, "... love of God is for the whole world. ..."Emmanuel Yartekwei Lartey, 2003.. This dimension includes, for example, the nature of God's creation, various social-social problems and systems, cultural systems, economic systems, political systems, and so on, which directly or indirectly affect human life. Giving place to these dimensions can overcome the problems of theology and the pastoral ministry, which are very individualistic. In this frame, humans are seen as related to the world in which they exist. Meanwhile, Clinebell explained his ideas about this dimension of wholeness, namely: (1) the unity of all human dimensions, namely body, spirit, and soul; (2) loving God with all one's soul, which in the contemporary sense of this dimension is an outpouring of human mental and emotional potential continuously through a lifelong learning process; (3) relational integrity; (4) ecological integrity; (5) the way humans relate to institutions that can encourage or hinder the development of human potential; and (6) spiritual wholeness.Clinebell.

Third, an interdisciplinary approach is needed because a holistic pastoral approach is concerned with the integrity of all aspects of human life and the world (the whole world). It means that to develop a holistic pastoral theology based on living human documents, we must involve and or utilize various fields of science, starting from theology itself as the main field, and other relevant sciences, including local wisdom. We will not be able to explain, understand, and interpret human existence (living human documents) from one field of science perspective only.

Fourth, at the practical level, a holistic pastoral approach is inter-professional, involving various professions and expertise that can enrich theology and the pastoral ministry itself. It is known as holistic, integrated pastoral ministry.Totok S. Wiryasaputra, 2012). Therefore, inter-professional teams or co-workers are essential in developing holistic pastoral praxis.

Fifth, a holistic pastoral certainly pays attention to the local context. We realize that there is no holistic pastoral approach that can be considered applicable to all contexts. Each context has its uniqueness, which is vital in developing a holistic pastoral theology based on living human documents.

\section{CONCLUSION}

From the descriptions above, it is clear that holistic pastoral theology based on living human documents is fundamental. On the one side, this effort can solve the problem of a too theoretical-academic pastoral theology (ignoring the praxis aspect). On the other side, the action can overcome the pastoral tendency that is too practical (missing the theoretical-academic element). In other words, this effort will help us to study and develop pastoral theology empirically, as well as help us to integrate the pastoral theories we have learned into actual ministry practice.

It also places people in various crises equal with counselors in theology and pastoral ministry. They are now seen and treated as complete human beings, who due to 
multiple factors, are experiencing a problem. It is where the church then has a vast opportunity to help those who are in trouble, including people who have been ignored and not listened to in the church and society.

In His journey and ministry while on earth, Jesus saw many people who were so tired and abandoned like sheep without a shepherd (Matt. 9:36). Jesus moved by the heart of compassion to them. With great tenderness, He called to them:

Come unto me, all ye that labour and are heavy laden, and I will give you rest. Take my yoke upon you, and learn of me; for I am meek and lowly in heart: and ye shall find rest unto your souls. For my yoke is easy, and my burden is light. (Matt. 11:28-30, King James).

\section{REFERENCES}

Bagus, Lorens. (2000). Kamus Filsafat. Jakarta: Gramedia Pustaka Utama.

Boisen, Anton T. (1952). The Exploration of the Inner World. New York: Harper Torchbooks.

Boisen, Anton T. (1960). Out of Depths: An Autobiographical Study of Mental Disorder and Religious Experience. New York: Harper \& Brothers Publishers.

Boisen, Anton T. (2005). The Living Human Document. In Robert C. Dykstra (Ed.), Images of Pastoral Care: Classic Reading (pp. 22-29). Missouri: Chalice Press.

Clinebell, Howard. (2002). Tipe-tipe Dasar Pendampingan dan Konseling Pastoral. Yogyakarta \& Jakarta: Kanisius \& BPK Gunung Mulia.

Dykstra, Robert C. (2005). Classical Images of Pastoral Care. In Robert C. Dykstra (Ed.), Images of Pastoral Care: Classic Reading (pp. 15-21). Missouri: Chalice Press.

Gerkin, Charles V. (1992). Konseling Pastoral dalam Transisi. Jakarta \& Yogyakarta: BPK Gunung Mulia \& Kanisius.

Haarsma, F. (1991). Pastoral dalam Dunia. Yogyakarta: Pusat Pastoral Yogyakarta.

Hulme, William E. (1981). Pastoral Care \& Counseling: Using the Unique Resources of the Christian Tradition. Minneapolis: Augsburg Publishing House.

Kemp, Hendrika Vande. (2004). Harry Stack Sullivan (1892-1949): Hero, ghost, and muse. The Psychotherapy Patient, 13(1-2), 7-61.

Krisetya, Mesach. (1990). Theologia Pastoral: Klinis dan Empiris? In PERSETIA (Ed.), Studi Institut PERSETIA tentang Pendidikan Pastoral Klinis (pp. 58-65). Jakarta: PERSETIA.

Krisetya, Mesach. (2015). Bela Rasa yang Dibagirasakan: Pedoman dan Pegangan para Pelayan dan Akademisi untuk Meningkatkan Pelayanan dan Konseling Pastoral. Jakarta: Duta Ministri.

Lartey, Emmanuel Yartekwei. (2003). In living color: An intercultural approach to pastoral care and counseling (Second Edi). London and Philadelphia: Jessica Kingsley Publishers.

Miller-McLemore, Bonnie J. (2005). The Living Human Web. In Robert C. Dykstra (Ed.), Images of Pastoral Care: Classic Reading (pp. 40-46). Missouri: Chalice Press.

Niklas, Gerald R. (2001). The Making of a Pastoral Person. New York: Alba House.

Nouwen, Henri J. M. (1968). Anton T. Boisen and Theology through Living Human Documents. Pastoral Psychology, 19(September), 49-63. https://doi.org/10.1007/bf01788381 


\section{Alokasih Gulo}

Pattison, Stephen. (1988). A Critique of Pastoral Care. London: SCM Press.

Susanto, Daniel. (1999). Clinical Pastoral Education and Its Significance for Indonesia: A Study of Transfer of CPE from the USA to Indonesia, illustrated by the CPE Transfer to the Netherlands. Kampen: Drukkerij van den Berg.

Susanto, Daniel. (2010). Pelayanan Pastoral Holistik. In Sekilas tentang Pelayanan Pastoral di Indonesia (pp. 15-38). Jakarta: GKI Menteng.

van Beek, Aart Martin. (1992). Strategi Pelayanan Terpadu: Suatu Pedoman Pastoral. Jakarta: Pelkesi.

van Beek, Aart Martin. (2002). Pastoral Counseling in Indonesia. American Journal of Pastoral Counseling, 5(1/2), 151-173.

van Rensburg, Johan Janse. (2010). A Holistic Approach to Pastoral Care and Poverty. Verbum et Ecclesia, 31(05 November), 1-7.

Wiryasaputra, Totok S. (2012). Pelayanan Kesehatan Jemaat: Konsep dan Penerapannya. Jakarta: Pelkesi. 